Article

\title{
The Effects of Knowledge Assets and Path Dependence in Innovations on Firm Value in the Korean Semiconductor Industry
}

\author{
Yoonkyo Cho \\ Department of International Trade and Economics, Graduate School, Hansung University, \\ 116 Samseongyo-ro 16-gil, Samseon-dong, Seongbuk-gu, Seoul 02876, Korea; ub11cho@gmail.com or \\ ykcho@hansung.ac.kr
}

Received: 13 February 2020; Accepted: 14 March 2020; Published: 16 March 2020

\begin{abstract}
This study investigated whether firms' knowledge assets and path dependence in their innovations affect firm value. For the analysis, I used 37 firms in the semiconductor industry in Korea. These firms were listed on the Korea Stock Exchange and the Korea Securities Dealers Association Automated Quotation as of 2010 and through 2015. The dependent variable was measured by return on assets as firm value, and the ordinary least squares estimation was used. The results showed that a firm's knowledge assets have a positive effect on firm value. In addition, when a firm creates new knowledge, if the firm follows path dependence by using its own knowledge, it has a positive effect on firm value. By contrast, when a firm conducts innovations using knowledge created by other firms, it has no effect on the value of the firm. Additionally, I found that technological innovation based on knowledge assets and path dependence has a positive effect on firm value in the short term but has no effect in the medium term. Thus, firms need to continue their innovation to maintain their competitive advantage and to use their existing knowledge in innovation in order to have high performance.
\end{abstract}

Keywords: knowledge assets; innovation; path dependence; semiconductor industry; firm value

\section{Introduction}

The technological environment changes rapidly, which increases uncertainty in the marketplace. In environments of high uncertainty, firms would not expect to achieve high performance due to high competition. The semiconductor industry is one of the most highly competitive industries in the development of new technologies and products [1,2]. The semiconductor industry invests a lot of capital and requires a certain amount of time from investment to production, and the risk of investment is high due to rapid technological change and short product life cycle [3]. Therefore, the ability of a firm to accurately forecast demand, timely investment, and timely market entry is critical. In addition, the semiconductor industry shows a strong first mover advantage in that firms that possess the prior art and that introduce new products ahead of their competitors enjoy more profits [4].

In recent years, the semiconductor industry's sales have increased globally, as shown in Figure 1. Sales of the semiconductor market in 2008 were $\$ 248,603$ million but increased by $53.6 \%$ to $\$ 463,412$ million in 2018. The recession in the global economy, which began in 2008, caused global semiconductor firms to suffer deficits, and many went bankrupt. By 2010, with the recovery of the global economy, semiconductor prices rose, and surviving semiconductor firms reorganized their market position and expanded production. Due to this global environment change, in 2010, sales increased sharply $(31.8 \%)$ from 2009.

In Korea, semiconductors have been ranked number 1 in the amount of total export for the past five years and have always been ranked top-tier in the export category since the 1990s [5]. In particular, 
Samsung Electronics and SK Hynix are increasing their market share in the global semiconductor market. Those two firms have been in the top 10 of the world's semiconductor sales for the past decade. As shown in Figure 1, the firms' market share in sales increased to 26\% in 2018 compared with a less than $10 \%$ share in the global semiconductor market in 2008. This rapid growth of Korean firms began with the replacement of the Double Data Rate 3 (DDR3) generation in memory semiconductor dynamic random access memory (DRAM) in 2010. In the DDR3 mass production technology war, Korea's Samsung Electronics and SK Hynix first entered the 40nm class 2GB DDR3 production, gaining technological power and market advantage.

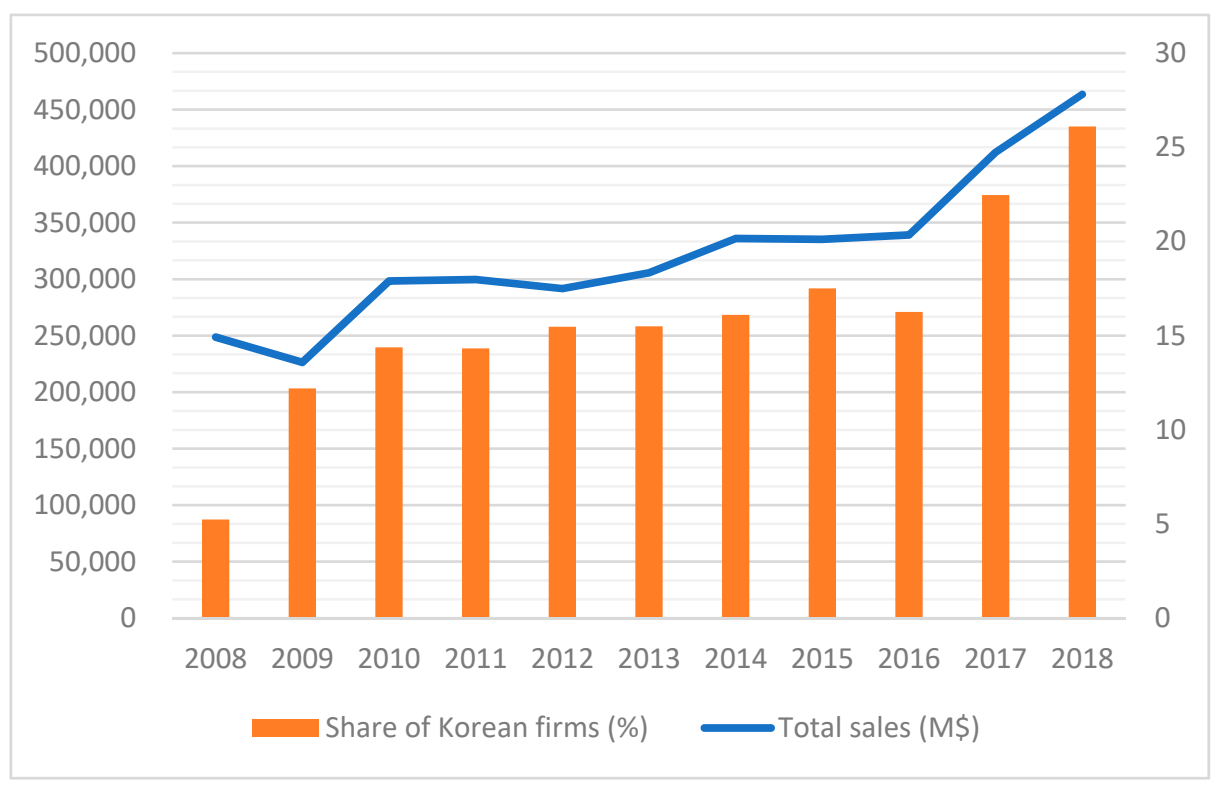

Figure 1. Sales of the global semiconductor industry and share of Korean firms [6,7].

The future prospect for the semiconductor market is not optimistic. Falling prices of semiconductor products, short life cycles of products, and the global economic recession are depressing the growth rate of the semiconductor industry. Furthermore, Korean firms are constantly competing with US and Japanese firms, and recently the sales of Chinese firms in the world market have been rapidly rising. In addition, Korea's semiconductor firms are concentrated in the memory sector, and it is another task to expand their business and compete in non-memory sectors. Korean firms, which must compete in this internal and external challenge, are pursuing steady research and development (R\&D) and innovation activities to maintain their competitive advantage.

Schumpeter argued that technological innovation is the most fundamental element of competition and is a major driving force in the development of firms and industries [8]. The key factor influencing innovations is the firm's knowledge assets [9]. Improving a firm's performance based on strategies of cost advantages and differentiation does not guarantee high performance in intensified competition and a rapidly changing market environment. As the technology and information era began, firms began to focus on the development of knowledge assets. Therefore, what kind of knowledge assets a firm has and how it manages them influence the success of the firm [10-12]. Previous studies have shown that investment in knowledge assets has a positive impact on firm performance [13-16]. However, because the types of knowledge assets vary, the value of the firm will depend on which knowledge assets are possessed.

Another reason knowledge assets do not have a positive effect on firm performance is the path of knowledge transfer. A firm's existing knowledge can affect the creation of new knowledge in two ways: First, it contributes to the knowledge creation of other firms. This occurs when firms acquire new knowledge from firms other than themselves when creating new technologies. Second, it contributes to the creation of knowledge by the firm itself. Firms can create new knowledge using 
their existing knowledge. Technology developed by a firm is the best technology that can be created by the firm using its resources, such as the knowledge, assets, and culture of the firm. If this technology is outstanding and another firm attempts to create new technology by embodying it through learning, it will be difficult to guarantee a successful result. Thus, uncertainties in processes and outcomes increase innovation costs. On the other hand, such uncertainty can be reduced if a firm uses path dependence in innovation, using its own knowledge rather than others' new technology [17-19]. Continued development of related technologies based on existing technologies also represents the sustainable growth potential of the firm [20]. Thus, path dependence in innovation will have a positive impact on firm performance.

The purpose of this study is to suggest an effective strategy to the firm to sustain its competitive advantage in the high-technology industry by analyzing the effect of the path dependence of the firm's technological innovation on the firm's value. To examine the effect, this study was based on two research questions: First, do a firm's knowledge assets affect the value of the firm? Second, if a firm's technological innovation follows path dependence, does it affect firm value? To address these questions, I analyzed the value in 2013 of 37 Korean semiconductor firms that had filed patents in Korea in 2010. The dependent variable was measured as return on assets (ROA) representing the value of the firm, and the variable for the knowledge asset and path dependence of the firm was measured by the number of patent applications and forward citation of the patent. The model was estimated using ordinary least squares (OLS) regression. I found that a firm's knowledge assets have a positive effect on firm value. In addition, the innovation by the path dependence of the firm has a positive effect on the value of the firm. However, this effect occurred in the short term and was not effective in the medium term.

The contribution of this study is in its finding that not all knowledge resources of a firm influence firm value. In other words, how knowledge assets are disseminated to create new knowledge is more important. For this, I have compared the two ways in which firm knowledge has influenced innovation and found that technological innovation by path dependence has a positive effect on firm value.

The rest of this paper is composed as follows: Chapter 2 describes background information and the main theoretical perspectives. In Chapter 3, I review the dataset, sampling methods, measurement of variables, and estimation model. Chapter 4 presents the empirical results of the hypothesis testing. Chapter 5 provides concluding remarks.

\section{Theoretical Background and Hypotheses}

\subsection{Firm Value}

The value of a firm can be represented by the performance achieved by the firm to date and its future development potential. A variety of factors affect firm value, which can be largely separated into tangible resources and intangible resources. The abundant tangible resources of a firm bring economies of scale to the firm and improve productivity, positively affecting the firm's performance and its value [21]. Similarly, the abundance and uniqueness of a firm's intangible resources, such as knowledge, know-how, human resources, and organizational culture, make it possible for a firm to have a competitive advantage and also positively influence firm value [22].

There are two ways to measure firm values: financial methods and non-financial methods. A firm's stock price and ROA are representative financial methods that measure firm value. However, given the recognition that the financial methods do not fully reflect a firm's value, non-financial methods have also been devised, of which the balance scorecard (BSC) is representative. The BSC focuses on balancing financial and non-financial measures in measuring firm performance [23]. This non-financial method plays a complementary role in evaluating firm value that cannot be achieved by the financial methods.

In a high-technology industry, a firm's knowledge resources play an important role in assessing its value. If the knowledge a firm possesses is valuable and unique, it will have a competitive advantage $[24,25]$. Additionally, the firm will use the knowledge to create the next new knowledge. 
Likewise, competitors will learn this knowledge from the firm to create relevant knowledge. If a firm's knowledge is used substantially in subsequent studies in an industry, the firm's technology can be considered to have a high value, which will have a positive impact on the firm's value.

\subsection{Knowledge Assets}

Knowledge assets can be defined as intellectual elements such as knowledge, information, and experience that create firm wealth in a broad sense [26]. Knowledge assets include both tangible and intangible assets that are the source of a firm's competitive advantage. Tangible knowledge resources of a firm usually mean documented or codified knowledge. It is relatively easy to convey such documented knowledge to other people or organizations, if only they have an understanding of that knowledge [27]. Intangible knowledge resources are usually described as tacit knowledge and are relatively difficult to communicate to other people or firms [28,29]. According to Edvinsson, intellectual property refers to invisible intangible assets, exemplified by knowledge, experience, technology embedded within the organization, and customer relationships [30]. Goodwill, structural assets, and human assets are also a firm's intellectual capital. [31]. To summarize, tacit knowledge includes organizational process and culture, management know-how, and knowledge embedded in employees. Tacit knowledge is not only difficult to document but also difficult for competitors to imitate because of the unique characteristics that only the organization has. Therefore, tacit knowledge allows the firm to maintain its competitive advantage for a long time. The knowledge assets possessed by the firm are its core competencies, and they are central to establishing an efficient and systematic knowledge base system in the organization. Therefore, the successful performance of a firm is determined by the management and utilization of the firm's knowledge resources [32-34].

In order to create such knowledge assets, firms invest substantially in R\&D. The performance of a firm's R\&D investment is closely related to patent rights. Patents can be judged as outputs of $R \& D$, and their number can be used to assess the efficiency of R\&D investment [35]. It is important for firms engaged in industries with high technological competition, such as the semiconductor industry, to gain a competitive advantage through continuous $R \& D$. By holding patents, a firm can expect to improve future productivity and profitability compared with its competitors. Patent rights can give their holders a monopoly power by forming a kind of entry barrier to the industry [36]. On the basis of this monopoly advantage in patent ownership, the firm will be able to expect stable technological development and revenue from patents within the patent retention period, which will have a positive impact on firm value.

Hypothesis 1. Knowledge assets have a positive effect on firm value.

\subsection{Technological Innovation by Path Dependence}

To create knowledge assets, firms use a variety of resources. First, a firm can create new knowledge by learning or borrowing from other firms' knowledge. Second, firms create new knowledge based on their own knowledge. Instead of trying to innovate based on totally new knowledge, firms using this resource are aiming at incremental innovation based on their previous knowledge. This can be explained from an evolutionary theory perspective.

Evolutionary technological innovation is a gradual process of creating new processes based on past ones [37]. According to evolutionary technology innovation, firms tend to search locally for information that will be employed in innovation [38]. This local search is based on bounded rationality, which was derived from the perspective of complementing the rationality assumed by the neoclassical economic theory. In the neoclassical economic theory, it is assumed that firms behave in a completely rational manner and that all information necessary for profit maximization can be used freely [39]. More specifically, to be able to assume such perfect rationality, first, complete information on all possible alternatives to the action should be obtained. Second, perfect prediction of the results to be 
obtained by each alternative should be possible. Third, a complete and consistent preference system should be presented for the results that each of these alternatives would bring [40]. However, it is impossible to satisfy these premises perfectly in reality.

Bounded rationality is attributed to the incompleteness of information. Unlike complete information, incomplete information, which is not defined in neoclassical economic theory, is costly to acquire and process, and this incomplete information can sometimes cause ambiguity as a result [41]. This ambiguity increases costs by making forecasting difficult and increasing uncertainty, which firms are motivated to avoid. Thus, firms try to do a local search when they do a new search. If firms use such a local search, their technological innovation is likely to be path-dependent.

The process of creating new technologies can be explained through the process of learning. Firms need learning to innovate. There are two ways of learning technology: First, learning to exploit technology is a learning activity that investigates new technical knowledge based on the technical knowledge already possessed by the firm, which is a form of path dependence in technology innovation. Second, exploration of technology learning can be defined as a learning activity that explores and adds to the technical knowledge of a new field that a firm has never learned before [42-44].

March argued that exploitation and exploration have different impacts on firm performance and that there is a trade-off between the two to compete to secure scarce firm resources [45]. When a firm's resources are limited and are allocated for exploitation and exploration, if the firm resources used for exploitation are increased, the resources used for exploration are reduced. Then, short-term firm performance is improved, but the possibility of enhancing long-term firm performance is reduced. On the other hand, if resources to invest in exploration are increased, short-term firm performance becomes hard to improve, but the possibility of increasing long-term firm performance increases. Therefore, companies can survive long-term in response to the pressures of environmental change while maintaining short-term management performance through an appropriate balance between exploitation and exploration.

Exploratory learning in technology can be accompanied by high risks and costs. First, learning new technologies that are unfamiliar to the firm may take a long time. Additionally, how well the firm adopts the new technology when the firm learns it depends on the firm's absorptive capacity. In the case of firms with a wealth of experience and resources, the absorptive capacity will be high enough to allow them to accept new technologies and contribute to their knowledge creation [46]. However, for a firm that does not have these, it will take a lot of time and costs to accept the new technology. Even if the firm learns and accepts the technology, it is hard to predict whether it will create new knowledge by combining it with its existing technology.

As a result, firms have a high incentive to create knowledge through learning by exploitation. During the learning process, the creation of knowledge takes place through routinized and history-dependent learning [47]. In other words, when using local search, the firm's new technology is not new in all aspects but is added or reconfigured from its existing knowledge. Therefore, if firms acquire knowledge in a path-dependent way, that is, if firms use their own accumulated technologies in creating new technologies, they can reduce risks and costs. This will have a positive impact on firm value by enabling stable knowledge creation. Additionally, the more a firm uses its own knowledge in innovation, the more likely the firm will have an image of itself as a firm with outstanding knowledge for the consecutive creation of knowledge, which will have a positive impact on firm value. Therefore, if a firm is path-dependent in technology development, it will have a high value.

Hypothesis 2. Path-dependent innovation has a positive effect on firm value. 


\section{Methodology}

\subsection{Sample}

This study investigated the effects of knowledge assets and innovation by path dependence on the value of a firm. For analysis, I collected data on semiconductor firms [48,49] because the semiconductor industry is one of the most innovative industries. I chose Korean firms because they have been able to preoccupy the market with new technologies, laying the foundation for leading the global market. The process was as follows: First, I determined which firms had applied for patents in the semiconductor field in Korea in 2010, when sales surged as the global semiconductor market was reorganized. There were 80 firms with H01L patents, which is the semiconductor field in the Original International Component Classification (IPC). Second, I determined which of the 80 semiconductor-manufacturing firms were registered with the Korea Stock Exchange and the Korean Securities Dealers Association automated quotation. Using the tenth Korea Standard Industry Classification, I identified 64 firms categorized by section $C$ manufacturing and by the specific industry codes 26 (manufacture of electronic components, computers, visual, sound, and communication equipment), 27 (manufacture of medical, precision, and optical instruments, watches, and clocks), 28 (manufacture of electrical equipment), and 29 (manufacture of other machinery and equipment). Third, among these firms, 37 continued to operate until 2015, and these were selected for this research, representing about $15.4 \%$ of all semiconductor firms in Korea.

\subsection{Measures}

\subsubsection{Dependent Variable}

The dependent variable in this study is the value of the firm. The value of the firm was measured by ROA three years after the patent application. ROA measures firms' short-term performance and is a useful measure of firm value as it shows the firm's return on total assets [50]. ROA is the ratio of net income profit to total assets.

\subsubsection{Independent Variables}

The first independent variable in this study is the firm's knowledge assets. I used the number of patent applications in the year 2010 to measure this variable. Patents provide access to accumulated technology in the semiconductor industry to help create advanced technologies and ensure that new products can be produced and sold legally. Thus, despite a short life cycle, the products with patents contribute to the firm's profit generation [51]. This is why semiconductor firms try to acquire as many patents as possible, and these patents become important knowledge assets. The second explanatory variable is technological innovation by path dependence. This was measured as the ratio of the number of self-forward citations to the number of patent applications. The most prevalent period of patent citation is the three years after the patent application [52,53]. According to Hall, Jaffe, and Trajtenberg, the citation of a patent after its application peaks within five years and then gradually declines [4]. In addition, semiconductors have a product life cycle of two to three years. After these periods, new technologies and products emerge, and the old ones become outdated. Therefore, I tried to measure the firm's performance through patent citation activities for the next three years of new technology development. Therefore, I counted the number of citations in the three years since the patent application and used this for our main analysis. As a robustness check, the patent citation period was increased to five years and compared with the citation analysis results for three years. In order to measure the situation in which the firm's new technology is cited by another firm, the number of forward citations by other firms was divided by the number of patent applications. 


\subsubsection{Control Variables}

This study controlled several variables that could affect the value of the firm. The first control variable was the age of the firm. Firms with high performance will be able to survive for a long time, and those with poor performance will not survive. Therefore, the fact that a firm is old means that its performance has been good, which can have a positive effect on its value. Each firm's age was measured by the difference between the year 2013 and the firm's establishment year. Second, I used $R \& D$ expenditures. High $R \& D$ expenditures can imply that the firm is undertaking a lot of $R \& D$ activities. These R\&D activities will have a positive effect on the value of the firm by allowing it to anticipate that the new technology will be available soon. R\&D expenditures were measured by the logarithm of the R\&D expenditure of the firm in the year 2013. Third, I used the size of the firm. The size of the firm is critical for gaining high performance and actively innovating. A larger firm can allow more diverse talents to work, which can lead to more innovation. Additionally, large firms are more likely to have more financial resources to support technological innovation than smaller ones. The size of these firms was measured by the log of the number of employees.

\subsection{Estimation}

To test the effect of knowledge assets and the path dependence of innovation on firm value, I used the following empirical models:

$$
\begin{aligned}
& \text { Firm Value }=\alpha 0+\beta 1 * \text { patents }+\beta 2 * \text { self_citation } \\
& +\beta 3 * \text { other_citation }+\beta 4 * \text { firm age }+\beta 5 * R \& D \text { expenditure }+\beta 6 * \text { firm size }+\varepsilon
\end{aligned}
$$

The final dataset consisted of cross-sectional data for 37 observations. For our methodology, I used OLS regressions. To reduce bias as adjusted for standard inflated errors, I used robust standard error formulas [54,55].

\section{Results and Discussion}

\subsection{Descriptive Statistics}

Table 1 shows the descriptive statistics of this study. In 2010, the number of patents applied for by a single firm was at least 1 and at most 59. For the following three years after a patent was applied for, the minimum self-citation rate was 0 , and the maximum was 1.25 . The ratio of patent citations by other firms was 0 at minimum and 3 at maximum. The firms were at least five years old and up to 78 years old.

Table 1. Descriptive statistics.

\begin{tabular}{cccccc}
\hline Variable & Obs. & Mean & Std. Dev. & Min & Max \\
\hline 1. ROA & 37 & 0.0310 & 0.0882 & -0.1905 & 0.1915 \\
2. Patents & 37 & 5.1351 & 9.7016 & 1 & 59 \\
3. Self citation & 37 & 0.2265 & 0.3627 & 0 & 1.25 \\
4. Other citation & 37 & 1.0038 & 0.8210 & 0 & 3 \\
5. Firm age & 37 & 25.8378 & 16.8218 & 5 & 78 \\
6. R\&D expenditure & 37 & 0.0425 & 0.0478 & 0.0003 & 0.2778 \\
7. Firm size & 37 & 6.0943 & 1.5247 & 4.3175 & 11.4700 \\
\hline
\end{tabular}

Table 2 shows the Pearson correlation between the variables used in this study. The correlation between all variables was relatively low. Furthermore, I conducted a variance inflation factor (VIF) test to check multicollinearity. All variables had a VIF coefficient of 1.76 or less and an average VIF coefficient of 1.37. In general, if the VIF coefficient is less than 10, it is assumed that the possibility of multicollinearity is low. Because all of the variables in this study show a VIF coefficient of less than 10, there is no serious multicollinearity problem. 
Table 2. Correlation.

\begin{tabular}{cccccccc}
\hline Variable & $\mathbf{1}$ & $\mathbf{2}$ & $\mathbf{3}$ & $\mathbf{4}$ & $\mathbf{5}$ & $\mathbf{6}$ & $\mathbf{7}$ \\
\hline 1. ROA & 1 & & & & & & \\
2. Patents & 0.2373 & 1 & & & & & \\
3. Self citation & 0.3906 & 0.2681 & 1 & & & & \\
4. Other citation & 0.0130 & -0.0513 & 0.1064 & 1 & & & \\
5. Firm age & 0.0064 & 0.3678 & -0.1364 & -0.0569 & 1 & & \\
6. R\&D expenditure & -0.4951 & -0.009 & -0.1252 & -0.1939 & -0.1823 & 1 & \\
7. Firm size & 0.2268 & 0.5669 & -0.0125 & -0.0881 & 0.4365 & 0.0077 & 1 \\
\hline
\end{tabular}

\subsection{Main Results}

Table 3 shows the results of our hypotheses. Each model tests a different hypothesis, and the final model with all variables added is shown in the last row, Model 5. Model 1 is a baseline model that adds control variables that can affect firm value. Model 2 is the result of testing Hypothesis 1 , indicating how knowledge assets affect firm value. Model 3 shows Hypothesis 2, regarding the effect of path dependence in innovation on firm value. Model 4 shows the effect on the value of a firm when its knowledge assets are cited by other firms for technology innovation.

Table 3. Firm value with three years of citations.

\begin{tabular}{|c|c|c|c|c|c|}
\hline & Model & Model & Model & Model & Model \\
\hline VARIABLES & 1 & 2 & 3 & 4 & 5 \\
\hline \multicolumn{6}{|l|}{$\begin{array}{c}\text { Independent } \\
\text { variables }\end{array}$} \\
\hline Patents & & $\begin{array}{c}0.00179 * \\
(0.000902)\end{array}$ & & & $\begin{array}{l}0.000587 \\
(0.00108)\end{array}$ \\
\hline Self citation & & & $\begin{array}{l}0.0751 * * \\
(0.0344)\end{array}$ & & $\begin{array}{l}0.0720 \text { * } \\
(0.0396)\end{array}$ \\
\hline Other citation & & & & $\begin{array}{c}-0.00858 \\
(0.0194)\end{array}$ & $\begin{array}{l}-0.0110 \\
(0.0179)\end{array}$ \\
\hline \multicolumn{6}{|l|}{ Control variables } \\
\hline Firm age & $\begin{array}{c}-0.00125^{* *} \\
(0.000602)\end{array}$ & $\begin{array}{c}-0.00141 \text { ** } \\
(0.000574)\end{array}$ & $\begin{array}{l}-0.000928 \\
(0.000587)\end{array}$ & $\begin{array}{c}-0.00128^{* *} \\
(0.000612)\end{array}$ & $\begin{array}{c}-0.00103 \\
(0.000616)\end{array}$ \\
\hline R\&D expenditure & $\begin{array}{c}-0.998 * * * \\
(0.152)\end{array}$ & $\begin{array}{c}-1.003 * * * \\
(0.153)\end{array}$ & $\begin{array}{c}-0.906^{* * *} \\
(0.163)\end{array}$ & $\begin{array}{c}-1.028^{* * *} \\
(0.172)\end{array}$ & $\begin{array}{c}-0.950 * * * \\
(0.183)\end{array}$ \\
\hline Firm size & $\begin{array}{l}0.0194 * * \\
(0.00777)\end{array}$ & $\begin{array}{c}0.0137 \\
(0.00990)\end{array}$ & $\begin{array}{l}0.0180 * * \\
(0.00770)\end{array}$ & $\begin{array}{l}0.0191 \text { ** } \\
(0.00783)\end{array}$ & $\begin{array}{c}0.0159 \\
(0.00996)\end{array}$ \\
\hline Constant & $\begin{array}{l}-0.0123 \\
(0.0511)\end{array}$ & $\begin{array}{c}0.0175 \\
(0.0589)\end{array}$ & $\begin{array}{l}-0.0334 \\
(0.0468)\end{array}$ & $\begin{array}{c}-0.0000937 \\
(0.0532)\end{array}$ & $\begin{array}{c}-0.00709 \\
(0.0596)\end{array}$ \\
\hline Observations & 37 & 37 & 37 & 37 & 37 \\
\hline R-squared & 0.342 & 0.368 & 0.433 & 0.348 & 0.446 \\
\hline
\end{tabular}

Note. Robust standard errors in parentheses $\left({ }^{* * *} p<0.01,{ }^{* *} p<0.05,{ }^{*} p<0.1\right)$.

The coefficient estimates in Table 3 indicate firm value in the year 2013. In Model 1, firms' age and R\&D expenditures have negative effects on firm value. I expected that long operating years would result in a large and diverse pool of knowledge and know-how, which in turn would have a positive effect on the value of the firm. However, in the electronics and semiconductor industries, where the technology is rapidly changing, it is shown that the age of the firm does not increase the value of the firm but may have the opposite effect. I conjecture that the older the firm, the slower it is to cope with new technological change compared with newly emerging technology firms. An increase in $R \& D$ expenditures was expected to have a positive effect on the value of the firm, because it indicates that the firm is working hard to create new knowledge. However, the expenditures for R\&D are also regarded as a part of the firm's costs and may result in failure to create new technology. Thus, it may have a negative effect on firm value. If the size of a firm is large, it has the potential to produce new 
value because there are many employees with various types of knowledge; this was borne out by the empirical analysis.

In Hypothesis 1, I expected that knowledge assets would have a positive effect on firm value. In Model 2, the coefficient of the number of patent applications is positive and statistically significant $(\beta=0.00179, p<0.1)$, and thus Hypothesis 1 was supported. When other variables are constant, the value of a firm increases by 0.00179 with every additional patent application.

In Hypothesis 2, I predicted that a firm's path dependence on technological innovation would have a positive effect on firm value. In Model 3, firms' self-citation of their innovation has a positive effect on firm value, and the coefficient is statistically significant $(\beta=0.0751, p<0.05)$, supporting Hypothesis 2. When a firm develops a new technology, the more the existing technology of the firm is used, the higher the value of the firm. Every time the self-citation rate for a firm's own previous patent increases by one unit, the value of the firm rises by 0.0751 .

\subsection{Robustness Check}

In addition, I used two robustness checks. First, I measured the cases in which patents were cited by other firms in order to investigate cases where path dependence was not found in the technological innovation. If a firm's patent is cited by other firms, it can be a good indication that the firm's technology is excellent at creating new knowledge, which can have a positive effect on the value of the firm. In Model 4 of Table 3, however, the citation of the firm's patents by other firms showed a negative impact on the value of the firm, though the coefficient is statistically insignificant.

Table 4 shows another robustness check setting the citation period to five years. Therefore, the firm value is measured in 2015, the patents are filed in 2010, the citation period is five years, and the firms' ages, R\&D expenditures, and numbers of employees are all measured in 2015.

Table 4. Firm value with five years of citations.

\begin{tabular}{|c|c|c|c|c|c|}
\hline & Model & Model & Model & Model & Model \\
\hline VARIABLES & 1 & 2 & 3 & 4 & 5 \\
\hline \multicolumn{6}{|l|}{ Independent variables } \\
\hline Patents & & $\begin{array}{c}0.00130 \\
(0.000908)\end{array}$ & & & $\begin{array}{c}0.00117 \\
(0.00118)\end{array}$ \\
\hline Self citation & & & $\begin{array}{c}0.0147 \\
(0.0171)\end{array}$ & & $\begin{array}{l}0.00932 \\
(0.0194)\end{array}$ \\
\hline Other citation & & & & $\begin{array}{c}0.0107 \\
(0.0116)\end{array}$ & $\begin{array}{c}0.0117 \\
(0.0113)\end{array}$ \\
\hline \multicolumn{6}{|l|}{ Control variables } \\
\hline Firm age & $\begin{array}{l}-0.000928 \\
(0.000939)\end{array}$ & $\begin{array}{c}-0.00104 \\
(0.000994)\end{array}$ & $\begin{array}{l}-0.000785 \\
(0.000960)\end{array}$ & $\begin{array}{c}-0.00107 \\
(0.000991)\end{array}$ & $\begin{array}{l}-0.00110 \\
(0.00108)\end{array}$ \\
\hline R\&D expenditure & $\begin{array}{c}-0.0790 \\
(0.158)\end{array}$ & $\begin{array}{c}-0.0793 \\
(0.173)\end{array}$ & $\begin{array}{c}-0.0459 \\
(0.157)\end{array}$ & $\begin{array}{c}-0.0625 \\
(0.155)\end{array}$ & $\begin{array}{c}-0.0403 \\
(0.178)\end{array}$ \\
\hline Firm size & $\begin{array}{c}0.0162 * \\
(0.00798)\end{array}$ & $\begin{array}{c}0.0119 \\
(0.00751)\end{array}$ & $\begin{array}{c}0.0159 * \\
(0.00784)\end{array}$ & $\begin{array}{c}0.0175 * \\
(0.00894)\end{array}$ & $\begin{array}{c}0.0136 \\
(0.00860)\end{array}$ \\
\hline Constant & $\begin{array}{l}-0.0243 \\
(0.0437)\end{array}$ & $\begin{array}{c}-0.00157 \\
(0.0448)\end{array}$ & $\begin{array}{l}-0.0344 \\
(0.0429)\end{array}$ & $\begin{array}{l}-0.0467 \\
(0.0542)\end{array}$ & $\begin{array}{l}-0.0347 \\
(0.0596)\end{array}$ \\
\hline Observations & 37 & 37 & 37 & 37 & 37 \\
\hline R-squared & 0.133 & 0.161 & 0.154 & 0.159 & 0.199 \\
\hline
\end{tabular}

Note. Robust standard errors in parentheses $\left({ }^{* *} p<0.01,{ }^{* *} p<0.05,{ }^{*} p<0.1\right)$.

Model 2 shows the results for Hypothesis 1, the effect of knowledge assets on firm value. Unlike in Table 3, firms' knowledge assets as of five years since the filing of a patent application show no impact on the value of the firm. Likewise, technological innovation by the path dependence of a firm did not affect the value of the firm, unlike the results for citations in the three-year period. 
In conclusion, the number of patents filed by a firm has a positive impact on its value. Additionally, it was found that the use of the firm's existing technology in its subsequent research or technological development positively affects firm value. Continuing research with the firm's previous technology may indicate that the firm's existing technology is good enough to contribute to new studies in the future. Thus, the path dependence in a firm's innovation can be expected to have a positive impact on firm value. However, although firms' knowledge assets have a positive effect on firm value in the short term (three years after patent application), they have no effect in the medium term (five years after patent application). Similarly, path dependence in innovation has a positive effect on firm value when new technology is developed for a short period. Although self-citations for up to three years after the filing of a patent were found to have a positive impact on the value of the firm, citations for up to five years had no effect on the value of the firm.

\section{Conclusions}

Rapidly changing technologies have a significant impact on a firm's survival and performance. To achieve better performance, a firm should consider what learning method is suitable to conduct its innovation. The purpose of this study was to investigate the effect of technology on firm value when a firm develops new technology through innovation activities.

According to the evolutionary theory, the acquisition of new knowledge follows path dependence, which has a positive effect on the firm's performance. Therefore, I examined the firms engaged in the semiconductor industry, in which innovation is most active in South Korea, and analyzed whether the path dependence of innovation affected the value of these firms. The results show that path-dependent innovation has a positive effect on firm value. However, although these effects persisted in the short term, they were not observed in the medium term. The creation of new knowledge plays a critical role in firm value. However, such new knowledge assets have a positive impact on firm value only in the short term. These results indicate that the impact of the technology on firm value is limited to shortly after the new technology is developed. The higher firm value cannot be maintained for a long time by one new technology in the rapidly changing semiconductor industry. This implies that firms should continuously develop new technologies to strive to maintain the high value of the firm for a long time.

Internal and external instability should continue for Korean firms in the semiconductor industry. The strategy under these circumstances will be key for determining whether the firm can maintain its competitive advantage and high performance. The effect of patents in the semiconductor industry is arguable. On the one side, managers insisted that patents can expect only minimal appropriating returns on R\&D investments [56,57]. While keeping with technological secrecy, entering the market quickly with new products can be more effective for a firm's profits [58]. Nevertheless, the patent applications of semiconductor firms have increased rapidly in the United States since the 1980s and have recently become a global trend. In the semiconductor industry, the exclusive right of a patent allows the firm to use the patent as a strategic mechanism, although other factors may have a greater impact on the firm's profitability. Firms can use their own patents quickly and usefully when developing new knowledge, thus reducing the hold-up that arises when other firms have patents. As a result, firms can quickly enter the market with new technologies and products and maintain technology lead times with other firms. Thus, firms pursue more patents, and patents become a critical resource for the firm's continuous development.

The path dependence of a firm's technological innovation shows that the firm pursues incremental innovation according to its routine rather than pursuing radical innovation. In other words, it is a process of development by exploiting the resources inside the firm rather than exploring the resources outside the firm in innovation activities. This study proved that this strategy has a positive effect on firm value, and it offers strategic implications for how managers should utilize the path dependence in their technology development portfolios.

Finally, this study has some limitations, which can lead to the proposal of future research topics. First, I used two sources of technology procurement to test the path dependence of a firm's innovation 
activities: internal and external. However, more specifically, if I check the transfer of knowledge by industry, I could understand which industry closely interacts with the semiconductor industry. Moreover, future research will also be able to examine the country's technological dependence by analyzing the firm's technology sources by country. Second, I examined the semiconductor industry, the leading innovation area. In future studies, it may be possible to examine which industries' firms are more strongly influenced by path dependence in technology innovation by simultaneously analyzing various industries. Those research attempts could lead to expansion of theories and derive more diverse implications.

Funding: This research received no external funding.

Acknowledgments: I am grateful to four anonymous reviewers and the editor for their valuable comments and suggestions throughout the review process.

Conflicts of Interest: The author declares no conflict of interest.

\section{References}

1. O'Reagan, D.; Fleming, L. The FinFET breakthrough and networks of innovation in the semiconductor industry, 1980-2005: Applying digital tools to the history of technology. Technol. Cult. 2018, 59, 251-288. [CrossRef]

2. Park, J.H.; Kook, S.H.; Im, H.; Eum, S.; Lee, C. Fabless semiconductor firms' financial performance determinant factors: Product platform efficiency and technological capability. Sustainability 2018, 10, 3373. [CrossRef]

3. Seitz, A.; Ehm, H.; Akkerman, R.; Osman, S. A robust supply chain planning framework for revenue management in the semiconductor industry. J. Revenue Pricing Manag. 2016, 15, 523-533. [CrossRef]

4. Hall, B.H.; Jaffe, A.B.; Trajtenberg, M. The NBER patent citation data file: Lessons, insights and methodological tools. Available online: https://www.nber.org/papers/w8498 (accessed on 4 March 2020).

5. Korea International Trade Association. Available online: http://stat.kita.net/stat/kts/pum/ItemImpExpList. screen (accessed on 4 March 2020).

6. World Semiconductor Trade Statistics. Available online: www.wsts.org (accessed on 4 March 2020).

7. IC Insights. Available online: www.icinsights.com (accessed on 4 March 2020).

8. Schumpeter, J.A. Capitalism, Socialism and Democracy; Harper \& Brothers: New York, NY, USA, 1942.

9. Donate, M.J.; de Pablo, J.D. The role of knowledge-oriented leadership in knowledge management practices and innovation. J. Bus. Res. 2015, 68, 360-370. [CrossRef]

10. Anzenbacher, A.; Wagner, M. The role of exploration and exploitation for innovation success: Effects of business models on organizational ambidexterity in the semiconductor industry. Int. Entrep. Manag. J. 2019. [CrossRef]

11. Colomo-Palacios, R.; García-Crespo, Á.; Gómez-Berbís, J.M.; Casado-Lumbreras, C.; Soto-Acosta, P. SemCASS: Technical competence assessment within software development teams enabled by semantics. Int. J. Soc. Humanist. Comput. 2010, 1, 232-245. [CrossRef]

12. Darroch, J. Knowledge management, innovation and firm performance. J. Knowl. Manag. 2005, 9, 101-115. [CrossRef]

13. Artz, K.W.; Norman, P.M.; Hatfield, D.E.; Cardinal, L.B. A longitudinal study of the impact of R\&D, patents, and product innovation on firm performance. J. Prod. Innovat. Manag. 2010, 27, 725-740.

14. Belderbos, R.; Carree, M.; Lokshin, B. Cooperative R\&D and firm performance. Res. Policy 2004, 33, 1477-1492.

15. Lin, C.; Li, B.; Wu, Y.J. Existing knowledge assets and disruptive innovation: The role of knowledge embeddedness and specificity. Sustainability 2018, 10, 342. [CrossRef]

16. Thornhill, S. Knowledge, innovation and firm performance in high-and low-technology regimes. J. Bus. Ventur. 2006, 21, 687-703. [CrossRef]

17. Camagni, R.P. Technological Change, Uncertainty and Innovation Networks: Towards A Dynamic Theory of Economic Space. In Regional Science; Boyce, D.E., Nijkam, P., Shefer, D., Eds.; Springer: Heidelberg, Berlin, 1991; pp. 211-249.

18. Yayavaram, S.; Srivastava, M.K.; Sarkar, M.B. Role of search for domain knowledge and architectural knowledge in alliance partner selection. Strateg. Manag. J. 2018, 39, 2277-2302. [CrossRef] 
19. Zollo, M.; Winter, S.G. Deliberate learning and the evolution of dynamic capabilities. Organ. Sci. 2002, 13, 339-351. [CrossRef]

20. Paruchuri, S.; Awate, S. Organizational knowledge networks and local search: The role of intra-organizational inventor networks. Strateg. Manag. J. 2017, 38, 657-675. [CrossRef]

21. Berndt, E.R. The Practice of Econometrics: Classic and Contemporary; Addison Wesley Publishing Company: Boston, MA, USA, 1991.

22. Chen, M.C.; Cheng, S.J.; Hwang, Y. An empirical investigation of the relationship between intellectual capital and firms' market value and financial performance. J. Intellect. Cap. 2005, 6, 159-176. [CrossRef]

23. Kaplan, R.S.; Norton, D.P. Linking the balanced scorecard to strategy. Calif. Manag. Rev. 1996, 39, 53-79. [CrossRef]

24. Boasson, V.; Boasson, E. Firm value, spatial knowledge flow, and innovation: evidence from patent citations. China Financ. Rev. Int. 2015, 5, 132-160. [CrossRef]

25. Collins, C.J.; Smith, K.G. Knowledge exchange and combination: The role of human resource practices in the performance of high-technology firms. Acad. Manag. J. 2006, 49, 544-560. [CrossRef]

26. Stewart, T.; Ruckdeschel, C. Intellectual capital: The new wealth of organizations. Perform. Improv. 1998, 37, 56-59. [CrossRef]

27. Saviotti, P.P. On the dynamics of appropriability, of tacit and of codified knowledge. Res. Policy 1998, 26, 843-856. [CrossRef]

28. Polanyi, M. The logic of tacit inference. Philosophy 1966, 41, 1-8. [CrossRef]

29. Agrawal, A. Engaging the inventor: Exploring licensing strategies for university inventions and the role of latent knowledge. Strateg. Manag. J. 2006, 27, 63-79. [CrossRef]

30. Edvinsson, L. Developing intellectual capital at Skandia. Long. Range. Plann. 1997, 30, 366-373. [CrossRef]

31. Brooking, A. Intellectual Capital; Cengage Learning EMEA: London, UK, 1998.

32. Alegre, J.; Sengupta, K.; Lapiedra, R. Knowledge management and innovation performance in a high-tech SMEs industry. Int. Small Bus. J. 2013, 31, 454-470. [CrossRef]

33. Pater, R.; Lewandowska, A. Human capital and innovativeness of the European Union regions. Innovat. Eur. J. Soc. Sci. Res. 2015, 28, 31-51. [CrossRef]

34. Zhao, R.; Sheng, X. Innovation-Related Diversification and Firm Value. Eur. Financ. Manag. 2017, 23, 475-518.

35. Singh, J. Distributed R\&D, cross-regional knowledge integration and quality of innovative output. Res. Policy 2008, 37, 77-96.

36. Bain, J.S. Barriers to New Competition, Their Character and Consequences in Manufacturing Industries; Harvard University Press: Cambridge, MA, USA, 1956.

37. Cantwell, J. Transnational Corporations and Innovatory Activities; Taylor \& Francis: Philadelphia, PA, USA, 1994.

38. Bell, G.G. Clusters, networks, and firm innovativeness. Strateg. Manag. J. 2005, 26, 287-295. [CrossRef]

39. Nelson, R.R.; Winter, S.G. Evolutionary theorizing in economics. J. Econ. Perspect. 2002, 16, 23-46. [CrossRef]

40. March, J.G.; Simon, H.A. Organizations; Wiley: New York, NY, USA, 1958.

41. March, J.G.; Olsen, J.P. Ambiguity and Choice in Organizations; Universitetsforlaget: Bergen, Norway, 1979.

42. Ahuja, G.; Morris Lampert, C. Entrepreneurship in the large corporation: A longitudinal study of how established firms create breakthrough inventions. Strateg. Manag. J. 2001, 22, 521-543. [CrossRef]

43. Katila, R. New product search over time: Past ideas in their prime? Acad. Manag. J. 2002, 45, 995-1010. [CrossRef]

44. Gupta, A.K.; Smith, K.G.; Shalley, C.E. The interplay between exploration and exploitation. Acad. Manag. J. 2006, 49, 693-706. [CrossRef]

45. March, J.G. Exploration and exploitation in organizational learning. Organ. Sci. 1991, 2, 71-87. [CrossRef]

46. Cohen, W.M.; Levinthal, D.A. Absorptive capacity: A new perspective on learning and innovation. Admin. Sci. Quart. 1990, 35, 128-152. [CrossRef]

47. Levitt, B.; March, J.G. Organizational learning. Annu. Rev. Sociol. 1988, 14, 319-338. [CrossRef]

48. DataGuide. Available online: www.dataguide.co.kr (accessed on 4 March 2020).

49. WIPS ON. Available online: www.wipson.com (accessed on 4 March 2020).

50. Lin, B.W.; Chen, C.J.; Wu, H.L. Patent portfolio diversity, technology strategy, and firm value. IEEE Trans. Eng. Manag. 2006, 53, 17-26. 
51. Galasso, A.; Schankerman, M. Patent rights, innovation, and firm exit. RAND J. Econ. 2018, 49, 64-86. [CrossRef]

52. Hall, B.H.; Jaffe, A.B.; Trajtenberg, M. Market value and patent citations: A first look. NBER Work. Pap. Ser. 2000. Available online: https://www.nber.org/papers/w7741 (accessed on 4 March 2020).

53. Jaffe, A.B.; Trajtenberg, M. International knowledge flows: Evidence from patent citations. Econ. Innov. New. Technol. 1999, 8, 105-136. [CrossRef]

54. Carpenter, M.A. The implications of strategy and social context for the relationship between top management team heterogeneity and firm performance. Strateg. Manag. J. 2002, 23, 275-284. [CrossRef]

55. Thompson, S.B. Simple formulas for standard errors that cluster by both firm and time. J. Financ. Econ. 2011, 99, 1-10. [CrossRef]

56. Cohen, W.M.; Nelson, R.R.; Walsh, J.P. Protecting Their Intellectual Assets: Appropriability Conditions and Why US Manufacturing Firms Patent (or not) (No. w7552); National Bureau of Economic Research: Cambridge, MA, USA, 2000.

57. Levin, R.C.; Klevorick, A.K.; Nelson, R.R.; Winter, S.G.; Gilbert, R.; Griliches, Z. Appropriating the returns from industrial research and development. Brook. Pap. Econ. Act. 1987, 3, 783-831. [CrossRef]

58. Hall, B.H.; Ziedonis, R.H. The patent paradox revisited: An empirical study of patenting in the US semiconductor industry 1979-1995. RAND J. Econ. 2001, 32, 101-128. [CrossRef]

(C) 2020 by the author. Licensee MDPI, Basel, Switzerland. This article is an open access article distributed under the terms and conditions of the Creative Commons Attribution (CC BY) license (http://creativecommons.org/licenses/by/4.0/). 